Троцько В. В., канд. військ. наук, ст. наук. співроб. ${ }^{1}$ (0000-0002-4656-0615); Троцько Л. Г. ${ }^{2}$

1 - Університет економіки і права “КРОК”, Київ;

2 - Військовий інститут телекомунікацій та інформатизації імені Героїв Крут, Київ;

3 - Центр воєнно-стратегічних досліджень Національного університету оборони України імені Івана Черняховського, Київ

\title{
Підхід до визначення послідовності реалізації задач для досягнення спроможностей економіки України з метою задоволення потреб оборони
}

Резюме. У статті запропоновано підхід до визначення послідовності задач для досягнення спроможностей економіки України з метою задоволення потреб оборони з використанням мурашиного алгоритму. Незважаючи, що цей метод перш за все використовується для пошуку оптимізаційних рішень в задачі комівояжера, вона може бути використана в оборонному плануванні. Застосування запропонованого підходу дає змогу визначити пріоритетність вирішуваних завдань для задоволення потреб оборони певного періоду планування.

Ключові слова: спроможності економіки; ройовий алгоритм; граф можливих маршрутів; планування оборонних ресурсів.

Постановка проблеми. У сучасних воєнно-політичних умовах Україна, зіштовхнувшись 3 явищем гібридної війни та здійснюючи захист свого суверенітету i територіальної цілісності, продовжує вживати заходів щодо посилення обороноздатності. За відсутності членства у воєнно-політичному блоці НАТО та ознак щодо зміни агресивного воєнно-політичного курсу Російської Федерації найважливішим питанням для нашої держави $є$ набуття спроможностей, необхідних для протистояння ворогові. У цих умовах актуальним залишається завдання раціонального планування оборонних ресурсів, складовою частиною якого $€$ визначення послідовності реалізації завдань для досягнення спроможностей економіки України із задоволення потреб оборони.

Аналіз останніх досліджень та публікацій. Тема оцінювання спроможностей держави i iï економіки, зокрема, щодо задоволення потреб оборони, регулярно згадується в керівних документах вищого військового керівництва держави та Міністерства оборони України.

На сьогодні фундаментальним документом 3 цього питання, безумовно, $\epsilon$ оборонний огляд. Сучасні підходи та досвід проведення у Міністерстві оборони і Збройних Силах України оборонного огляду у 2014-2015 роках детально викладені в монографії [1]. У цій праці детально розглядається процес проведення оборонного огляду, оцінювання спроможностей, їх набуття та всі питання, які пов'язані 3 плануванням процесу їx досягнення, включаючи розгляд закордонного досвіду. Однак конкретне питання визначення послідовності реалізації завдань для досягнення спроможностей економіки України у цій роботі не розглядається.

У низці наукових робіт вивчалися питання створення методологічних засад планування розвитку Збройних Сил і суміжні 3 цим питання, які близькі за напрямом до оцінювання спроможностей економіки для задоволення потреб оборони [2-5]. У цих роботах авторами грунтовано пророблені питання щодо визначення потреб Збройних Сил у ресурсах (економічних, фінансових, ресурсних) для досягнення ними необхідних спроможностей, оцінювання ефективності оборонного планування та суміжні 3 ними питання. Проте в цих роботах дослідники оминули питання можливостей економіки, зокрема, питання, яким чином можливе таке досягнення (за яких умов і які задачі вважати пріоритетними). Близьким до цього актуального питання $є$ розгляд у статті [6] переліку напрямів за якими необхідно розвивати воєнно-економічний потенціал, зокрема i в зовнішньоекономічній сфері. Поряд 3 аналізом у цій роботі відсутні методичні підходи або методики, які б дали змогу оцінювати завдання щодо економіки України в контексті забезпечення оборонних потреб і визначення того, яким чином (у якій послідовності) ці завдання вирішувати. Отже, аналіз останніх досліджень i публікацій показав, що формалізовані підходи щодо визначення послідовності реалізації завдань 
для досягнення спроможностей економіки України недостатньо повно розроблені.

Метою статті $\epsilon$ розроблення

методичного підходу для визначення послідовності реалізації завдань для досягнення спроможностей економіки України для задоволення потреб оборони 3 використанням елементів штучного інтелекту.

Виклад основного матеріалу. В основу методичного підходу, який пропонується, покладене припущення, що існує певна точка досяжності, до якої необхідно привести економіку України для того, щоб здійснювати стійке забезпечення спроможностей. До того ж уважається, що для економіки держави забезпечення спроможностей для задоволення потреб Збройних Сил являє собою безперервний динамічний процес, який потребує постійного розвитку та розв'язання низки ключових проблемних питань (завдань) протягом певного періоду реалізації завдань оборонного планування.

До таких завдань відносяться:

створення виробничих потужностей для випуску продукції оборонного призначення в кількості, яка б задовольняла потреби Збройних Сил;

налагодження кооперативних зв'язків 3 іншими державами для організації доступу до сировини та матеріалів, необхідних для випуску продукції оборонного призначення;

підготовка кваліфікованих кадрів, що можуть забезпечити функціонування та створення промислових потужностей для задоволення оборонних потреб;

організація доступу до існуючих технологій, необхідних для випуску продукції оборонного призначення;

організація наукових досліджень, включно з випробуваннями техніки, матеріалів i розв'язання інших питань, пов'язаних iз задоволенням потреб оборони.

Зазначений перелік, хоч $\mathrm{i}$ охоплює основні завдання, пов'язані із задоволенням потреб оборони, не є вичерпним і може бути розширений відповідно до завдань оборонного планування. Вирішення зазначених ключових завдань являє собою складний процес у якому кожне питання розв'язується на різних рівнях державного планування і пов'язане 3 розв'язанням інших питань. Створення певної формалізованої структури, яка б окреслювала функціонування всього комплексу спроможностей економіки щодо задоволення потреб оборони значно ускладнене. Така складність обумовлена специфікою виробництва окремих видів техніки та озброєння, складністю організації кооперативних зв'язків з іншими державами в галузі випуску озброєння, конкурентними перешкодами, браком необхідних фінансових ресурсів та іншими причинами. Отже важко однозначно визначити у якій послідовності слід вирішувати завдання щодо задоволення потреб оборони (визначити пріоритетність цих завдань).

Одним із методів, який дає змогу певною мірою враховувати вплив зазначених ускладнень є метод мурашиного алгоритму або алгоритму оптимізації мурашиної колонії (ant colony optimization, ACO), який відноситься до так званих ройових алгоритмів. Цей метод, запропонований Марко Дорідо [7], на сьогодні знайшов широке застосування для розв'язання різноманітних задач в економіці та техніці.

Сутність методу полягає у знаходженні маршруту на графі, який відповідав би певним оптимізаційним критеріям. Не обов'язково, щоб цей граф був евклідовим. Достатньо знати інформацію, яка характеризує довжину ребер (в умовних одиницях) та додаткову інформацію про динамічні характеристики переходів (так звана, кількість феромонів) i саму характеристику алгоритму (так звану “жадібність" та “стадність"). Зазначений алгоритм використовує біологічну аналогію дій колонії мурах, які шукають поживу через розвідування маршруту, розбризкуючи на шляху пахучу речовину (феромон). Орієнтуючись на запах цієї речовини інші мурахи багато разів повторюють маршрути 3 певною ймовірністю. 3 часом феромон випаровується. Чим коротший шлях, тим більша ймовірність, що пахуча речовина не випарується i слугуватиме орієнтиром для доступу до поживи найкоротшим шляхом. Термін “феромон” у мурашиному алгоритмі $\epsilon$ сталим і використовується на рівні $з$ іншими технічними термінами.

Зразок графа для оцінювання досяжності необхідних спроможностей економіки для задоволення потреб Збройних Сил України наведено на рис. 1. На цьому рисунку вузлами 3 номерами позначені ключові задачі, відповідно до номерів зазначених у переліку. Літерою “'П' позначений початок обходу графа, а літерою “ $\boldsymbol{K}$ ” - кінець. Завдання полягає у знаходженні мінімального маршруту за зазначеними ребрами. Цей маршрут означатиме пріоритетну послідовність задач (досягнення кінцевої мети 3 мінімальними затратами для певного планового періоду).

Адаптовані характеристики мурашиного алгоритму визначення послідовності реалізації 
задач для досягнення спроможностей економіки України 3 метою задоволення потреб оборони, наведені в табл. 1. Чисельні значення характеристик у цій таблиці не співпадають 3 реальними i мають ілюстративний характер.
Неважко помітити, що наведена задача оптимізації є класичною задачею комівояжера, розв’язання якої здійснюється нетривіальним способом.

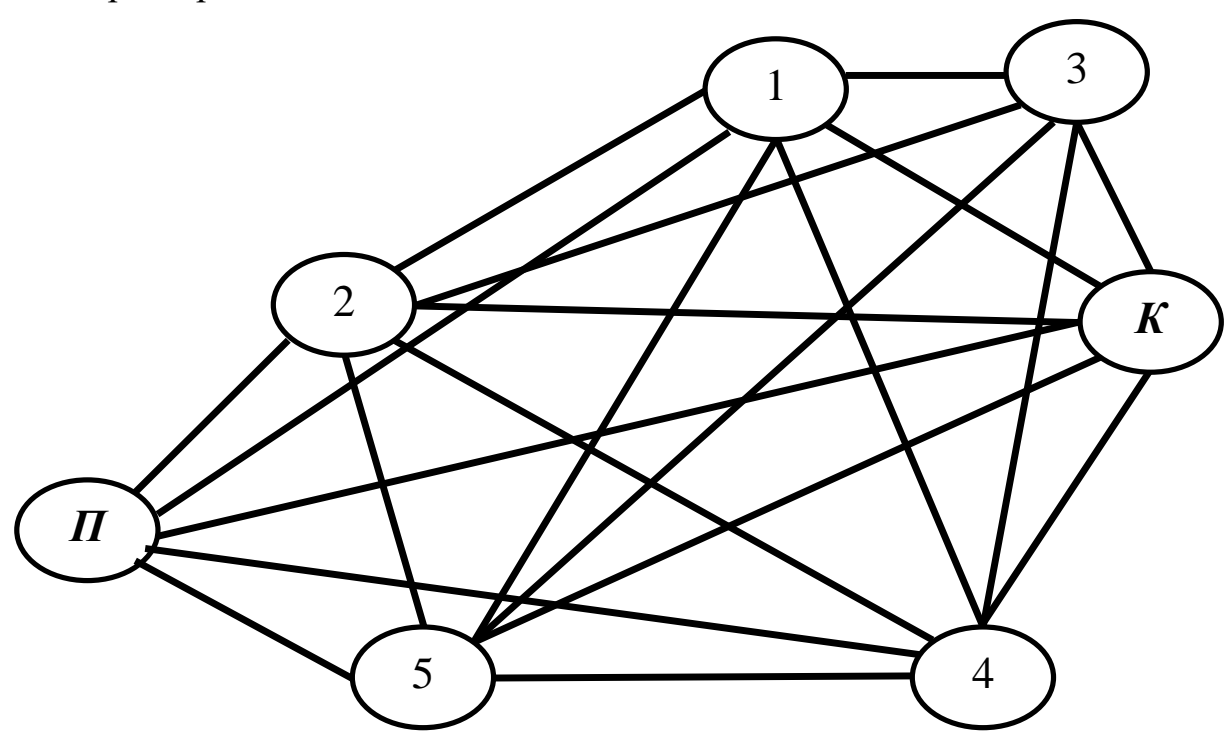

Рис. 1. Граф для визначення послідовності реалізації задач для досягнення спроможностей економіки України з метою задоволення потреб оборони

Таблиця 1

Вихідна інформація для визначення послідовності реалізації задач для досягнення спроможностей економіки України з метою задоволення потреб оборони

\begin{tabular}{|c|c|c|c|}
\hline \multirow{2}{*}{ Non } & $\begin{array}{c}\text { Перехід від однісї } \\
\text { ключової проблеми до } \\
\text { іншої }\end{array}$ & $\begin{array}{c}\text { Вартість ресурсів для } \\
\text { досягнення спроможностей }\end{array}$ & $\begin{array}{c}\text { Потреби 3бройних Сил у } \\
\text { спроможностях у балах }\end{array}$ \\
\cline { 2 - 4 } & $\mathbf{m}$ & $\boldsymbol{l}$ & $\boldsymbol{f}$ \\
\hline 1 & $\Pi-1$ & 56 & 2 \\
\hline 2 & $\Pi-2$ & 39 & 2 \\
\hline 4 & $\Pi-3$ & 43 & 1 \\
\hline 5 & $\Pi-4$ & 39 & 3 \\
\hline 6 & $\Pi-5$ & 50 & 3 \\
\hline 7 & $1-K$ & 40 & 2 \\
\hline 8 & $1-2$ & 61 & 3 \\
\hline 9 & $1-3$ & 41 & 1 \\
\hline 10 & $1-4$ & 54 & 2 \\
\hline 11 & $1-5$ & 62 & 1 \\
\hline 12 & $2-K$ & 37 & 2 \\
\hline 13 & $2-3$ & 23 & 3 \\
\hline 14 & $2-4$ & 57 & 1 \\
\hline 15 & $2-5$ & 41 & 3 \\
\hline 16 & $3-K$ & 44 & 2 \\
\hline 17 & $3-4$ & 59 & 1 \\
\hline 18 & $3-5$ & 29 & 2 \\
\hline 19 & $4-K$ & 35 & 3 \\
\hline 20 & $4-5$ & 48 & \\
\hline
\end{tabular}

У табл. 1 описані всі можливі маршрути для переходу в інші вузли графа під час виходу з початкового вузла $-\boldsymbol{\Pi}$ і досягнення кінцевого вузла $-\boldsymbol{K}$. До того ж повернення в точку $\boldsymbol{\Pi}$ не передбачається. Наприклад, знаходячись у вузлі 1 можна перейти у кінцевий вузол - $\boldsymbol{\kappa}$, та у вузли $2,3,4$ та 5 (повернення у вузол $\boldsymbol{\Pi}$ не допускається). Переходи 1-2 та 2-1 рівнозначні.
Ймовірність переходу по і-му маршруту графа рис. 1 обчислюється за формулою

$$
P_{i}=\frac{l_{i}^{q} \cdot f_{i}^{p}}{\sum_{i=0}^{N} l_{i}^{q} \cdot f_{i}^{p}},
$$

де $P_{i}$ - імовірність досягнення спроможностей для $i$-ї задачі; 
$l_{i}^{q}$ - вартість ресурсів для досягнення спроможностей під час розв'язання $i$-ї задачі;

$f_{i}^{p}$ - потреби Збройних Сил України, які досягаються під час розв'язання $i$-ї задачі;

$Q$ - величина, що характеризує ступінь врахування вартості ресурсів для досягнення спроможностей;

$P$ - величина, що визначає ступінь врахування потреб Збройних Сил України;

$N$-кількість можливих маршрутів переходів 3 одного вузла графа в інші.

Рішення стосовно переходу до будьякого вузла приймається за умови виконання $P_{i}=\max$, дляі $=\overline{1, \mathrm{~N}}$.

У формулі (1), значення величин $p$ i $q$ знаходяться в межах $0 \ldots 1$. Їх сума завжди дорівнює 1 , тобто $(p+q=1)$. При $q=1, p=0$ значення величини $f_{i}^{p}$ дорівнює $1, \mathrm{i}$ у такому випадку потреби Збройних Сил України у спроможностях ігноруються, а враховується тільки вартість ресурсів. Коли $q=0$, а $p=1$, відповідно, ігнорується вартість ресурсів, а враховуються лише потреби. Щоб врахувати і потреби, i вартість ресурсів найбільш раціональним підходом $\epsilon$ зробити їх рівнозначними величинами $(q=0,5 ; p=0,5)$.

Пропонований підхід, який грунтується на описаному методі складається 3 кількох етапів.

Периий етап - створення переліку задач для досягнення спроможностей економіки України з метою задоволення потреб оборони на певний період планування. Очевидно, що кількість цих задач для короткострокового, середньострокового та довгострокового планування буде різною. Відмінним також будуть зміст і обсяг кожної задачі.

Другий eman - формування таблиці вихідних даних 3 відповідною оцінкою вартості ресурсів для здійснення переходу (виконання кожної задачі).

Tретій етап - здійснення розрахунків 3 використанням комп'ютерної програми. Створення такої програми з огляду на простоту методу не $є$ складним завданням. Результат використання такої програми для здійснення розрахунків відповідно до даних, наведений у табл. 1 та на рис. 2.

\section{Таблиця вихідних даних}

\section{Мурашиний алгоритм}

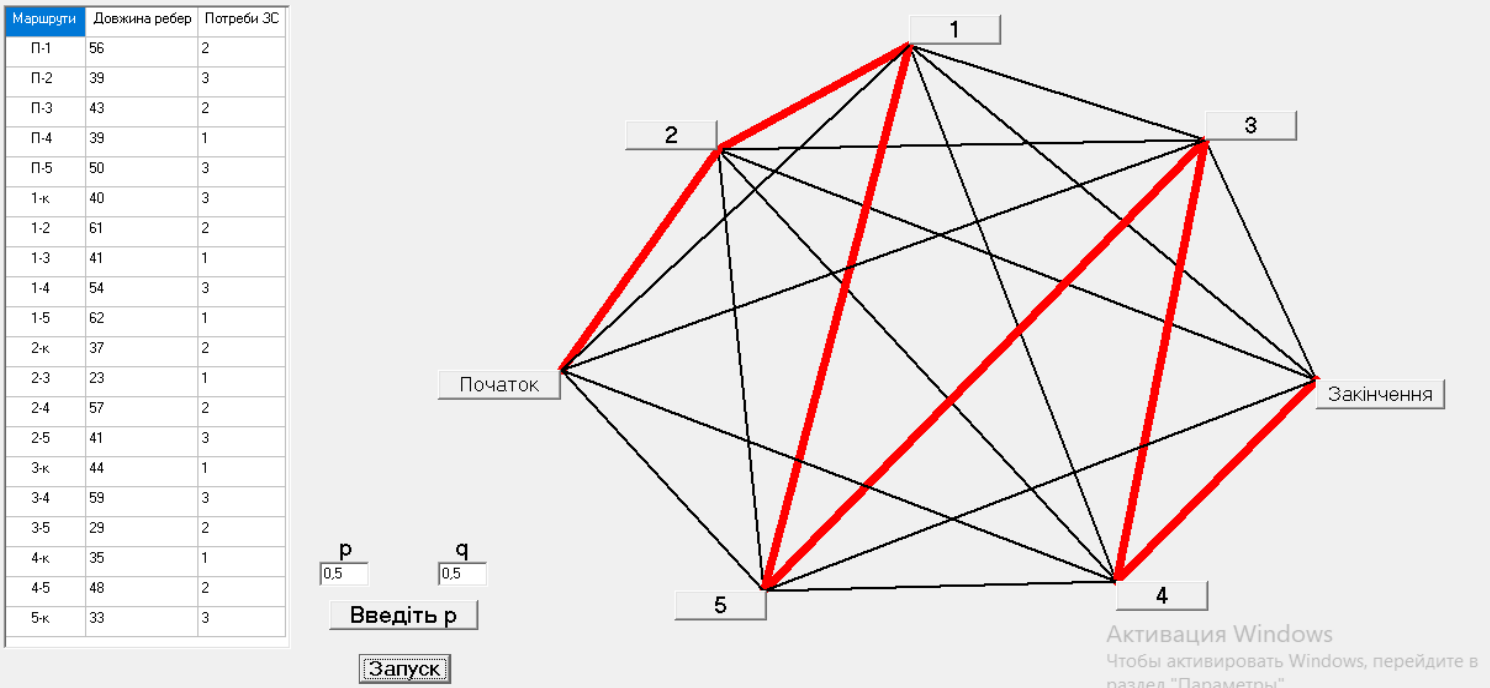

Рис. 2. Результат визначення послідовності реалізації задач для досягнення спроможностей економіки України з метою задоволення потреб оборони за допомогою комп'ютерної програми

Із результату наведеного на рис. 2 для досягнення спроможностей щодо задоволення потреб оборони послідовність реалізації задач для досягнення спроможностей економіки України має бути такою П-2-1-5-3-4-К. Вузли графа були позначені відповідно до наведеного переліку завдань:

налагодження кооперативних зв'язків 3 іншими державами для організації доступу до сировини та матеріалів, необхідних для випуску продукції оборонного призначення; створення виробничих потужностей для випуску продукції оборонного призначення в кількості, яка б задовольняла потреби Збройних Сил;

організація наукових досліджень, включно з випробуваннями техніки, матеріалів i вирішення інших питань, пов'язаних із задоволенням потреб оборони;

підготовка кваліфікованих кадрів, що можуть забезпечити функціонування та 
створення промислових потужностей для задоволення оборонних потреб;

організація доступу до існуючих технологій, необхідних для випуску продукції оборонного призначення.

Четвертий етап - здійснення аналізу отриманого результату та можливе його коригування. На цьому етапі важливим моментом є оцінювання того, настільки отриманий результат відповідає умовам досягнення економічних спроможностей за відповідний період планування. Можливо існують умови, за яких розраховану послідовність задач, незважаючи на оптимальне рішення, неможливо реалізувати через певні економічні або технологічні причини.

Запропонований підхід має низку переваг серед яких є простота формалізації, яка дає змогу визначити послідовність реалізації задач для досягнення спроможностей економіки України 3 метою задоволення потреб оборони. Іншою перевагою $\epsilon$ простота реалізації обчислювальної процедури. Також, iз застосуванням наведеного підходу можливо здійснювати оцінювання маючи досить велику кількість проблем (10 і більше).

Тим часом запропонований підхід можна вважати лише початковим етапом для здійснення більш глибокого i масштабного оцінювання, яке має включати використання кількох різних способів, зокрема експертних, для отримання результату максимально наближеного до адекватної оцінки, який можливо реалізувати в практиці оборонного планування.

Висновки та перспективи подальших досліджень. Найбільш проблемним питанням у застосуванні запропонованого підходу слід вважати формування таблиці вихідних даних, для якої потрібний ретельний i виважений набір даних. Отже надалі треба здійснити розроблення методів для якісного формування таких таблиць у контексті конкретних завдань. Одним із таких методів має бути метод оцінювання потреб Збройних Сил у спроможностях у балах. Можливо, що для кожного періоду планування таке оцінювання відрізнятиметься. Також, слід зазначити, що застосування наведеного підходу для вирішення низки специфічних завдань короткострокового оборонного планування, де наявність великої кількості завдань поєднується 3 досить короткими термінами для їх реалізації. Отже, необхідно приділити увагу дослідженню практичного застосування запропонованого підходу до низки завдань притаманних короткостроковому оборонному плануванню.

\section{СПИСОК ВИКОРИСТАНОЇ ЛІТЕРАТУРИ}

1. Оборонний огляд: український вимір 2014 2018: монографія / Ф. Саганюк, А. Павліковський, П. Щипанський, В. Павленко та ін. ; за заг. ред. д військ. н., проф. І. Руснака. Київ : МО та ГШ ЗС України, НУОУ, 2019. 196 с.

2. Романченко I. C., Богданович В. Ю., Дєнєжкін М. М. Теоретико-методологічні засади побудови системи управління ефективністю планування та виконання програм розвитку Збройних Сил України. Наука $і$ оборона. 2015. № 3/4. С. 50-55.

3. Основні аспекти воєнно-економічної безпеки України та можливі шляхи іiі забезпечення на середньострокову перспективу (2016-2020 рр.) / О. М. Семененко, О. Г. Водчиць, Р. В. Бойко, В. В. Кострач, А. Д. Бердочник. Системи озброєння $і$ військова техніка. 2016. № 3 (47). С. $123-129$.

4. Методика розподілу оборонного бюджету України між складовими сил оборони 3 урахуванням показників потреб та пріоритетності завдань цих складових на плановий рік / О. М. Семененко, О. Г. Водчиць, Р. В. Бойко, С. П. Василенко, O. I. Кремешний. Наука і техніка Повітряних Сил Збройних Сил Украӥни. 2017. № 4 (29). С. 123-131. DOI: https://doi.org/ 10.30748/nitps.2017.29.17.

5. Дєнєжкін М. М. Управління оборонними ресурсами: методичний підхід до визначення потреби в ресурсах на розвиток збройних сил у ході оборонного планування. URL: https://www.google.com/url?sa=t\&rct=j\&q=\&esrc=s \&source $=$ web $\& c d=2 \&$ ved $=2$ ahUKE $\quad$ wiGncSGs KDlAhUswsQBHW74AOkQFjABegQIAhAC\&url=h ttp\%3A\%2F\%2Fwww.hups.mil. gov.ua\%2Fperiodicapp $\% 2$ Farticle\%2F18339\%2Fnitps

2018 _1_19.pdf\&usg=AOvVaw12XwIgzc5Y

ZsSvWwljLOEB.

6. Бойко Р. В., Кремешний О. І., Семененко О. М., Чекед I. B. Воєнно-еконономічні аспекти забезпечення національної безпеки України. URL: https://www.google.com/url?sa=t\&rct=j\&q=\&esrc=s

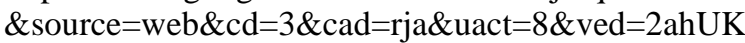
EwiJr92bsaDlAhVB06YKHegfBWQQFjACegQIBh AC\&url=http\%3A\%2F\%2Fwww.hups.mil.gov.ua\%2 Fperiodic-app $\% 2$ Farticle $\% 2 F 2862$

\%2Fzhups_2011_2_7.pdf\&usg=AOvVaw2G_Oco5b x Oy7tYslGg9PWI

7. Dorigo M., Maniezzo V., Colorni A. The Ant System: Optimization by a Colony of Cooperating Agents. IEEE Trans. on Systems, Man and Cybernetics. Part B. 1996. № 1. Vol. 26. P. 29-41.

8. Штовба С. Д., Рудий О. М. Мурашині алгоритми оптимізації.

URL: https://www.google.com/url?sa=t\&rct=j\&q=\&esrc=s $\&$ source $=$ web $\& c d=6 \& v e d=2$ ahUKEwjdtqKLra DlAhVizqYKHUBiA5QQFjAFegQIBBAC\&url=http 
Троцько В. В., канд. воен. наук, ст. науч. сотр. ${ }^{\text {; }}$

Троцько Л. Г. ${ }^{2}$;

Руденская Г. В. ${ }^{3}$

1 - Университет экономики и права “КРОК”;

2 - Военный институт телекоммуникаций и информатизации имени Героев Крут;

3 - Центр военно-стратегических исследований Национального университета обороны Украины имени Ивана Черняховского, Киев

Подход к определению последовательности реализации задач для достижения возможностей экономики Украины с целью удовлетворения потребностей обороны

Резюме. В статье предложен подход к определению последовательности задач для достижения возможностей экономики Украины с целью удовлетворения потребностей обороны с использованием муравьиного алгоритма. Несмотря на то, что этот метод используется главным образом для поиска оптимизационных решений в задаче коммивояжера, она может быть использована в оборонном планировании. Применение предложенного подхода позволяет определить приоритетность решаемых задач для удовлетворения потребностей обороны для определенного периода планирования.

Ключевые слова: возможности экономики; роевой алгоритм; граф возможных маршрутов; планирование оборонных ресурсов.

\section{Trotsko, PhD (Military), senior researcher ${ }^{1}$;}

\section{Trotsko ${ }^{2}$;}

G. Rudenska ${ }^{3}$

1 - University of Economics and Law "CROK"

2 - Institute of Telecommunications and Information Technologies the name of the Heroes of Krut, Kyiv;

${ }^{3}$ - Center for Military and Strategic Studies of the National Defence University of Ukraine named after Ivan Cherniakhovskyi, Kyiv

An approach to determining the sequence of tasks to achieve the capabilities of the Ukrainian economy in order to meet the needs of defense

Resume. The article proposes an approach to determining the sequence of tasks to achieve the capabilities of the Ukrainian economy in order to meet the needs of defense using an ant algorithm. Despite the fact that this method is mainly used to search for optimization solutions in the traveling salesman problem, it can be used in defense planning. The application of the proposed approach allows us to determine the priority of the tasks to be met to meet the needs of defense for a certain planning period.

Keywords: economic opportunities; swarm algorithm; graph of possible routes; defense resource planning. 